\title{
Microbial Community Analysis of Food-Spoilage Bacteria in Commercial Custard Creams Using Culture-Dependent and Independent Methods
}

\author{
K. Arakawa, ${ }^{*}$ Y. Kawai, ${ }^{, 1}$ H. lioka,† M. Tanioka, $†$ J. Nishimura, ${ }^{*}$ H. Kitazawa, ${ }^{*}$ K. Tsurumi, $†$ and T. Saito* \\ *Laboratory of Animal Products Chemistry, Graduate School of Agricultural Science, Tohoku University, 1-1 Tsutsumidori-Amamiyamachi, \\ Aoba-ku, Sendai 981-8555, Japan \\ †Technology Development Laboratory, Tsukishima Foods Industry Co., Ltd., 3-17-9 Higashi Kasai, Edogawa-ku, Tokyo 134-8520, Japan
}

\section{ABSTRACT}

Custard cream is made from highly nutritive raw materials such as milk and sugar and is easily spoiled by the multiplication of specific microbial contaminants or residents. However, this spoilage microbial community has not been studied. We determined the spoilage microbiota in commercial custard creams using culturedependent and independent methods. Using the culture-dependent analysis with various agar media, 185 bacterial colonies and 43 eukaryal colonies were isolated from 7 commercial custard cream products. All bacterial isolates were morphologically, physiologically, and genetically identified as bacilli, staphylococci, lactic acid bacteria, and psychrotrophic gram-negative rods. Using culture-independent molecular analysis, the PCR-denaturing gradient gel electrophoresis technique, spoilage of the commercial custard creams was found to be caused by bacilli, staphylococci, lactic acid bacteria, psychrotrophic gram-negative rods, Anoxybacillus sp., Caurobacter sp., and Streptococcus sp. bacteria. The detected spoilage bacteria were the same species as previously detected in spoiled milk products and shown in other reports, suggesting that spoilage bacteria in a raw material easily grow in processed foods made from milk. We determined the spoilage microbial communities in commercial custard creams, and these are the first data concerning spoilage microbiota in nonfermented processed foods using a culture-independent analysis. Our study will be useful for the manufacture and safe preservation of dairy products because the first step toward safe food preservation by food manufacturers is to understand the spoilage microbiota in a target food to select optimal preservatives and to reduce the use of food additives.

Key words: custard cream, spoilage microbiota, $16 \mathrm{~S}$ rDNA, polymerase chain reaction-denaturing gradient gel electrophoresis

Received September 6, 2007.

Accepted March 26, 2008.

${ }^{1}$ Corresponding author: ykawai@bios.tohoku.ac.jp

\section{INTRODUCTION}

Custard creams used in cream puffs, pastries, and cakes are made from highly nutritive raw materials such as milk, starch, and sugar. Custard creams shipped by suppliers are generally aseptic; however, they encounter bacterial contamination during reprocessing, preservation, transportation, and sales. Growth of the contaminating bacteria not only causes deterioration in taste and flavor but can also cause food poisoning (e.g., Staphylococcus aureus). To avoid this, suppliers have to control the bacterial growth by sterilization using heat and food additives. However, many customers do not want artificial additives because these artifacts may negatively affect the flavor and impair health. Therefore, suppliers have recently tried to control bacterial growth using as few additives as possible or using biopreservatives such as bacteriocins (Kawai and Saito, 2002; Cotter et al., 2005).

The milk spoilage microbiota was previously determined using a culture-dependent analysis (Boor and Murphy, 2002) wherein the bacterial species of isolates were identified from their morphological, physiological, and genetic characteristics. Using culture, the predominant spoilage in pasteurized milk was revealed to be caused by thermoduric bacteria surviving pasteurization (Micrococcus, Enterococcus, Lactobacillus, Streptococcus, and Corynebacterium spp. and the spores of $B a-$ cillus and Clostridium) and psychrotrophic gram-negative motile rods as postpasteurization contaminants. However, spoilage microbiota of custard creams made primarily from milk has not been studied.

Recently, culture-independent molecular methods have been developed to improve understanding of a total microbiota because the use of selective culturedependent methods does not determine the entire environmental bacterial diversity (Amann et al., 1995). Total DNA samples extracted from a complex microbial environment are used to identify bacterial species composed of the dominant population using PCR and denaturing gradient gel electrophoresis (DGGE; Muyzer et al., 1993). The species-specific $16 \mathrm{~S}$ rDNAs amplified 
from the extracted DNA are separated on the basis of sequence differences using DGGE, and are sequenced to identify the bacterial species. The culture-independent analysis using the PCR-DGGE technique can rapidly detect both cultivable and uncultivable bacteria and has been used for many studies concerning environmental microbial ecology (Torsvik et al., 1998; Ercolini, 2004). The microbial communities of fermented foods such as pozol (Ampe et al., 1999; ben Omar and Ampe, 2000), fermented sausage (Cocolin et al., 2001; Fontana et al., 2005a,b), Sicilian cheese (Randazzo et al., 2002), cassava (Ampe et al., 2001; Miambi et al., 2003), kimchi (Lee et al., 2005), and fermented dairy products (Fasoli et al., 2003; Obodai and Dodd, 2006) have been determined using the PCR-DGGE technique, but few microbiota analyses of putrid foods have been performed using the culture-independent method.

In this study, spoilage bacterial communities of commercial custard creams were determined using the culture-dependent and independent methods with the objective to aid in determining and optimizing the kinds and the amount of food additives to extend the shelf life and preserve this fragile food.

\section{MATERIALS AND METHODS}

\section{Sampling}

Custard cream samples (A to G) were selected from 7 types of commercial cream puffs, pastries, and cakes containing custard creams produced at our factory (Tsukishima Foods Industry, Tokyo, Japan). They were accelerated to putrefy by holding at 15 or $30^{\circ} \mathrm{C}$ for 15 or $30 \mathrm{~d}$ in a noncontaminative environment until $>10^{4}$ $\mathrm{cfu} / \mathrm{g}$ of viable microbial cells were detected using culture on plate count agar (PCA; Eiken Chemical, Tokyo, Japan). Samples A and B were from shelf-stable products and samples $\mathrm{C}$ to $\mathrm{G}$ were chilled products.

\section{Microbial DNA Extraction from Commercial Custard Creams}

The bacterial cells in the putrid custard creams were disrupted to extract the total DNA: $0.8 \mathrm{~mL}$ of the 1:10 custard cream dilution in PBS ( $\mathrm{pH} 7.3$ ) was mixed with $1.0 \mathrm{~g}$ of glass beads ( $0.1 \mathrm{~mm}$, Tomy Seiko, Tokyo, Japan) and crushed using a Micro Smash MS-100R (Tomy Seiko) for $5 \mathrm{~min}$ at 5,000 rpm. Purification of the total DNA extracted from the disrupted aqueous phase was performed using a QIAamp DNA Blood Mini Kit (Qiagen, Germantown, $\mathrm{MD}$ ) according to the manufacturer's instructions and the method of Cenci-Goga et al. (2004).

\section{Isolation of Bacterial Strains}

Custard creams diluted with PBS were inoculated on PCA, nutrient agar (NA; Oxoid, Hampshire, UK), trypticase soy agar (TSA; Difco, Detroit, MI), and de Man, Rogosa, Sharpe agar (MRS, Difco) plates. The plates were incubated at 25,30 , and $37^{\circ} \mathrm{C}$ for $24 \mathrm{~h}$ under aerobic and anaerobic conditions. After incubation, 4 or 5 colonies were isolated from each plate. The eukaryal colonies were determined using PCR amplification of 26S rRNA genes (26S rDNA) with the primers NL1 and LS2 shown in Table 1 according to the method of Cocolin et al. (2000).

\section{PCR-DGGE of the Isolates}

To easily classify the isolated bacterial strains according to their species and to clarify the diversity of bacterial species present in the putrid custard cream, PCR-DGGE for all of the isolates was performed using the V3 region on the 16S rRNA genes (16S rDNA), which is the species-specific sequence and shows a constant mobility in the DGGE gel. In this study, isolates having the same DGGE banding pattern were considered as the same species and one or more representative isolate(s) were used in the next identification steps (sequencing and morphological, physiological, and genetic analyses).

The 16S rDNA V3 region of all isolates were amplified using direct-colony PCR with the bacterial universal primers gc338f including a GC clamp and 518r (Table 1). Amplification was performed in a $20-\mu \mathrm{L}$ reaction mixture containing $10 \times$ PCR buffer (Takara Bio, Shiga, Japan), $200 \mu M$ dNTPs, $0.4 \mu M$ each primer, $0.5 \mathrm{U}$ of Taq polymerase (Takara Bio), and bacterial cell template DNA. The cycling program was $94^{\circ} \mathrm{C}$ for $10 \mathrm{~min}$ followed by 40 cycles of $94^{\circ} \mathrm{C}$ for $30 \mathrm{~s}, 57^{\circ} \mathrm{C}$ for $30 \mathrm{~s}$, $72^{\circ} \mathrm{C}$ for $30 \mathrm{~s}$; and then a final extension of $72^{\circ} \mathrm{C}$ for 5 min. The PCR products were electrophoresed in $2.0 \%$ (wt/vol) agarose gels and the bands were observed using ethidium bromide stain. The amplicons were purified using a commercial kit, MagExtractor (Toyobo, Osaka, Japan) and were separated using DGGE with a BioRad Dcode System (Bio-Rad Laboratories, Hercules, CA) following the procedure described by Muyzer et al. (1993). Denaturing gels consisted of 6.5\% ( $\mathrm{vol} / \mathrm{vol})$ polyacrylamide and $1 \times$ Tris-acetate EDTA with a gradient ranging from 40 to $60 \%$ urea-formamide [100\% was defined as $7 M$ urea and $40 \%$ (vol/vol) formamide]. The electrophoresis was performed for $12 \mathrm{~h}$ at $100 \mathrm{~V}$ in 0.5 $\times$ Tris-acetate EDTA buffer at $65^{\circ} \mathrm{C}$. Gels were stained for 60 min using SYBR Gold nucleic acid gel stain solution (Invitrogen, Carlsbad, CA) and photographed under UV transillumination. 
Table 1. Polymerase chain reaction primers used in this study

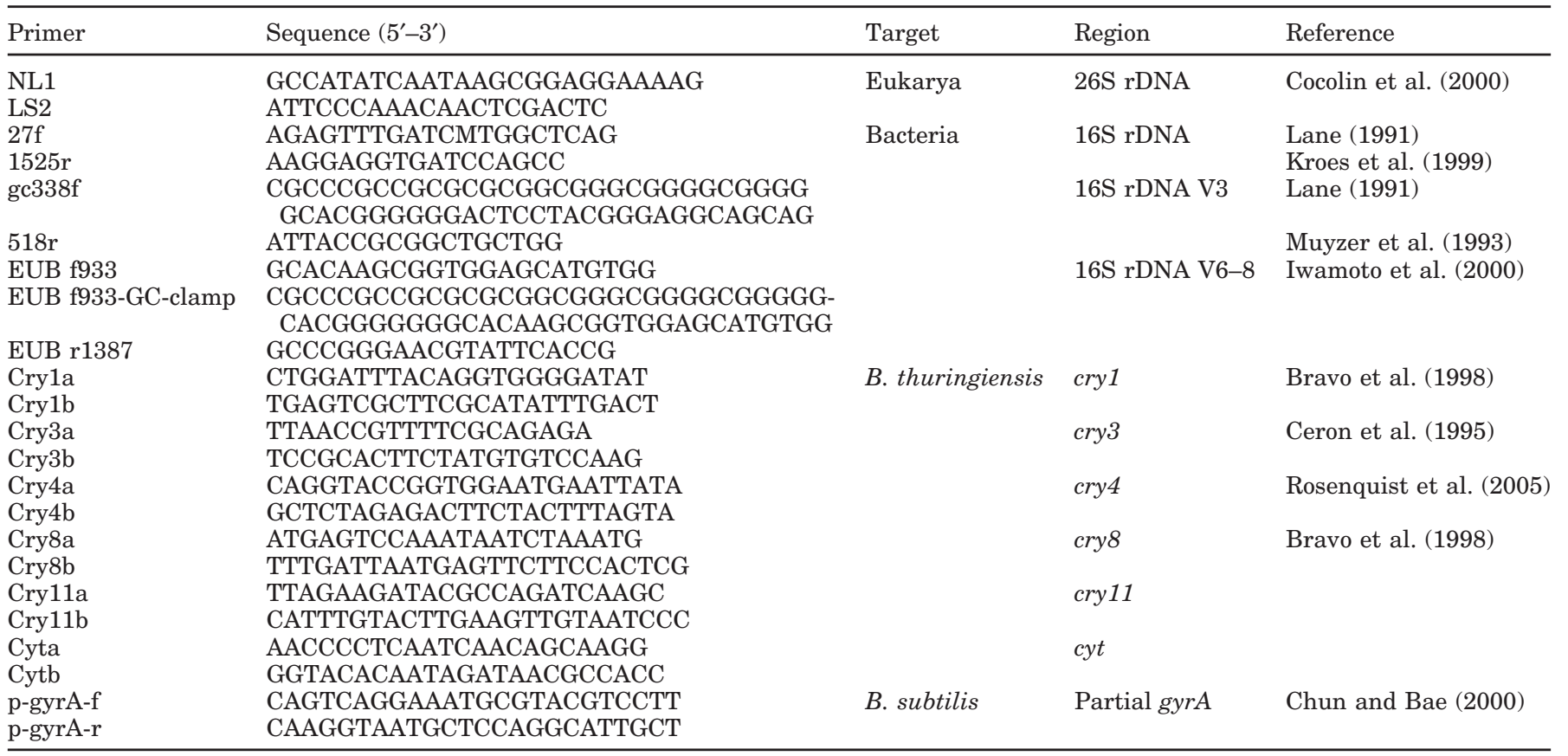

\section{$16 S$ rDNA Sequence of the Isolates}

The 16S rDNA V1-3 and V6-8 regions from the representative isolates selected by differences in the band position of the PCR-DGGE were amplified using the direct-colony PCR with the primer pairs $27 \mathrm{f}+518 \mathrm{r}$ and EUB 1933 + EUB r1387 (Table 1), respectively. The PCR mixture and the cycling program were the same as above, except for the annealing temperature at $54^{\circ} \mathrm{C}$ for the $\mathrm{V} 1-3$ region and at $62^{\circ} \mathrm{C}$ for the $\mathrm{V} 6-8$ region. After electrophoresis and purification, the amplicons were sequenced using the dideoxy chain termination method with the BigDye Terminators v1.1 Cycle Sequencing Kit (Applied Biosystems, Foster City, CA) and an ABI PRISM 3100 Genetic Analyzer (Applied Biosystems). Sequence identities were determined using BLAST comparisons to the GenBank database.

\section{Morphological Analysis}

All of the selected isolates were observed using an optical microscope (Olympus BX-40, Olympus, Tokyo, Japan) and a transmission electron microscope (Hitachi H-8100, Tokyo, Japan). Optical microscopy was performed after the isolates were gram-stained (Nissui Pharmaceutical, Tokyo, Japan).

\section{Physiological Analysis}

Physiological analyses of the selected isolates were performed using the oxidase producing test (Eiken
Chemical), sulfide indole motility (SIM) medium (Eiken Chemical), API $50 \mathrm{CH}$ (bioMérieux, Marcy l'Etoile, France), and API Staph (bioMérieux) following the manufacturer's instructions.

\section{Species and Subspecies Identification}

Food spoilage Bacillus cereus is phenotypically and genotypically similar to Bacillus thuringiensis, where B. thuringiensis secretes the insecticidal crystal (Cry) protein coded on the cry gene. To determine if the isolates secreted the Cry protein using optical microscopy, the $B$. cereus-like isolates were stained using ZiehlNeelsen carbol-fuchsin stain solution (Merck KGaA, Darmstadt, Germany) according to the method of Harmon (1982). Bacillus cereus IFO13494, IFO13690, and JCM $2152^{\mathrm{T}}$ were employed as negative controls, and $B$. thuringiensis NBRC13865 and NBRC13866 were used as positive controls. Possession of the primary cry genes (cry 1, cry 3, cry 4, cry 8 , and cry 11 ) and cyt gene coding for the supplementary cytolytic protein was determined using direct-colony PCR with the primers listed in Table 1 using the methods of Ceron et al. (1995), Bravo et al. (1998), and Rosenquist et al. (2005).

Bacillus subtilis is divided into 2 subspecies, B. subtilis ssp. subtilis and B. subtilis ssp. spizizenii, on the basis of cell-wall chemistry and DNA-DNA relatedness especially in partial gyrA sequences coding for the DNA gyrase subunit A. The PCR-amplified gyrA using primers p-gyrA-f and p-gyrA-r (Table 1) from B. subtilis 
strains isolated from the putrid custard cream was sequenced according to the method of Chun and Bae (2000) and its sequence was compared with those in the GenBank database.

Leuconostoc mesenteroides is divided into 3 subspecies, Leu. mesenteroides ssp. mesenteroides, Leu. mesenteroides ssp. cremoris, and Leu. mesenteroides ssp. dextranicum. To determine the subspecies we employed tests for acid production from arabinose on the API 50 $\mathrm{CH}$ (bioMérieux) and dextran formation in 5 and $10 \%$ (wt/vol) sucrose agar with reference to the method of Beukes et al. (2001).

Identification of Achromobacter denitrificans was performed using an oxidation fermentation basal medium (Eiken Chemical) adding $1.0 \%$ (wt/vol) xylose. The closely related Achromobacter xylosoxidans is able to metabolize xylose but $A$. denitrificans does not grow in the xylose medium.

Two similar fluorescein-producing Pseudomonas species, $P$. fluorescens and $P$. putida, were differentiated using the test for gelatin liquefaction at $22^{\circ} \mathrm{C}$ for $60 \mathrm{~h}$ according to the method of Blazevic et al. (1973).

\section{Culture-Independent Analysis using PCR-DGGE and Genome Sequencing}

In addition to the culture-dependent method described above, spoilage bacterial communities in the commercial custard creams were determined with a culture-independent method using the PCR-DGGE technique. The 16S rDNA sequences of the spoilage bacteria were amplified using the touchdown PCR method with the bacterial universal primers, $27 \mathrm{f}$ and 1525r (Table 1). The total DNA extracted from the putrid custard creams were used as the first templates. Then, the V6-8 regions of the 16S rDNA were amplified using the touchdown PCR method with EUB f933-GCclamp including a GC clamp and EUB r1387 primers (Table 1). The reaction mixture was $10 \times$ PCR buffer (Toyobo), $200 \mathrm{~m} M$ dNTPs, $1.0 \mathrm{~m} M \mathrm{MgSO}_{4}, 0.3 \mu M$ each primer, $0.4 \mathrm{U}$ of KOD plus DNA polymerase (Toyobo), and $0.8 \mu \mathrm{L}$ of appropriately diluted template DNA in a final volume of $20 \mu \mathrm{L}$. The first PCR program was $94^{\circ} \mathrm{C}$ for 2 min followed by 30 cycles of $94^{\circ} \mathrm{C}$ for $15 \mathrm{~s}$, 59 to $49^{\circ} \mathrm{C}$ (decreasing $2^{\circ} \mathrm{C}$ per cycle 5 times) for $30 \mathrm{~s}$, $68^{\circ} \mathrm{C}$ for $2 \mathrm{~min}$, and a final extension at $68^{\circ} \mathrm{C}$ for $7 \mathrm{~min}$. The second PCR program was $94^{\circ} \mathrm{C}$ for $2 \mathrm{~min}$; followed by 36 cycles: $94^{\circ} \mathrm{C}$ for $15 \mathrm{~s}, 67$ to $57^{\circ} \mathrm{C}$ (decreasing $2^{\circ} \mathrm{C}$ per cycle 6 times) for $30 \mathrm{~s}, 68^{\circ} \mathrm{C}$ for $1 \mathrm{~min}$; and then $68^{\circ} \mathrm{C}$ for $5 \mathrm{~min}$. After PCR, electrophoresis, and purification of the PCR products, the amplicons were separated using DGGE as described above. The DGGE bands were excised with a sterile scalpel, ground with a sterile glass slide, and eluted in $20 \mu \mathrm{L}$ of sterile water.
The 16S rDNA V6-8 amplicons from each DGGE band were reamplified and sequenced as described above. The spoilage bacterial communities in the commercial custard creams were determined using the sequence data compared with the GenBank database.

\section{RESULTS}

\section{Determining Spoilage Bacterial Isolate Identity using 165 rDNA}

Each sample of custard cream (A to G) had $>10^{4} \mathrm{cfu} /$ $\mathrm{g}$ of viable cells using the colony count on PCA. A total of 228 colonies were isolated on PCA, NA, TSA, and MRS agar plates from the diluted solutions of each sample. Using PCR amplification of the $16 \mathrm{~S}$ and $26 \mathrm{~S}$ rDNA showed that 185 colonies among the 228 colonies were bacterial cells and the other 43 colonies were eukaryal cells.

For the 185 colonies identified as bacterial cells, the V3 regions of the 16S rDNA were amplified using the bacterial universal primers gc $338 \mathrm{f}$ and 518r, and their amplicons were used for DGGE analysis. The DGGE banding patterns after gel staining showed 185 isolates classified into some groups of the same species as shown in Table 2. Then, 1 to 3 strain(s) were selected as representatives from each group (Table 2) and the V1-3 and the V6-8 regions of their 16S rDNA were sequenced. Closest relative species in each group as shown in Table 2 were identified from the sequence identities as determined using BLAST comparisons to the GenBank database. This analysis showed that the spoilage bacterial 16S rDNA sequences were from Enterococcus faecalis, Enterococcus faecium, Lactococcus lactis ssp. lactis, and $P$. fluorescens and were identified at the species level; other spoilage bacteria were semi-identified to genus and general group.

\section{Morphological and Physiological Analysis of the Isolates}

The 26 bacterial strains (Table 2) selected by PCRDGGE were observed by optical microscopy using Gram stain and transmission electron microscopy. The stainability and morphology of the 26 strains are shown in Table 3. The observations correlated with the estimation of their bacterial species (semi-) identified from their partial 16S rDNA sequences.

Physiological characteristics and motility of the 26 strains using the oxidase test and the SIM medium test are shown in Table 3 . The patterns of carbohydrate metabolism determined by the API kits identified the strains closer to species (Table 3). Bacillus amyloliquefaciens, B. subtilis, Lactobacillus paracasei ssp. paracasei, Leu. mesenteroides, Staphylococcus saprophyticus 
Table 2. Species identification of the spoilage bacteria isolated from the putrid custard creams using PCR-denaturing gradient gel electrophoresis and sequencing of the V1-3 and V6-8 regions on their 16S rDNA

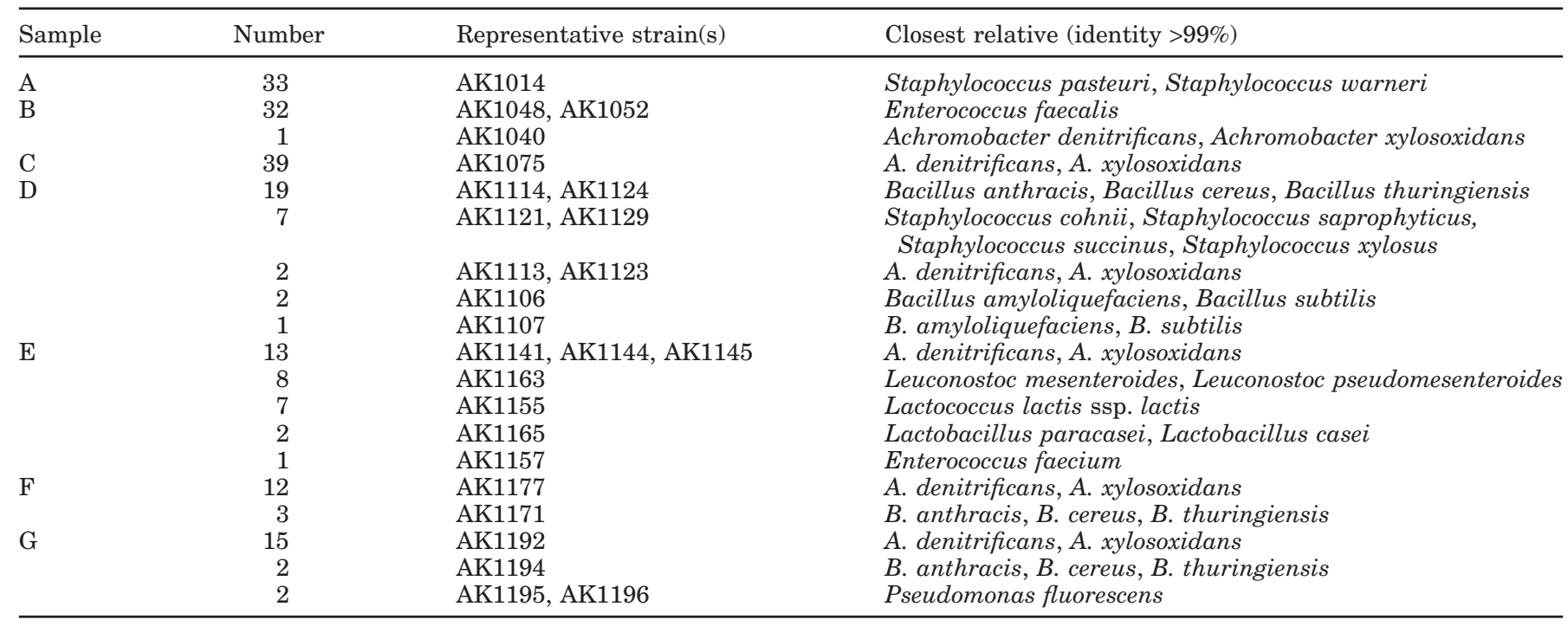

ssp. saprophyticus, and Staphylococcus warneri were identified as the primary spoilage bacteria forming communities in the putrid custard creams.

\section{Individual Identification of Isolated Spoilage Bacteria}

Bacillus cereus-like isolates (AK1114, AK1124, AK1171, AK1194, and AK1232) were identified as $B$. cereus or $B$. thuringiensis using genetic and physiological analysis. The secretion of the Cry protein and possession of its related genes (cry and cyt genes) occur only in B. thuringiensis strains. We did not find the Cry protein, cry genes, or cyt gene in the negative control strains or in the 5 target strains. The positive control strains secreted the Cry protein and possessed the cry 1 gene. Therefore, all of the isolated $B$. cereus-like strains were identified as $B$. cereus.

The subspecies of $B$. subtilis AK1107 was determined using gyrA gene sequencing. The homology with $99 \%$ identity was with $B$. subtilis ssp. subtilis strain KCTC3135, whereas the strain had $94 \%$ identity with B. subtilis ssp. spizizenii NRRL B-23049. Hence, strain AK1107 was identified as B. subtilis ssp. subtilis.

Subspecies of Leu. mesenteroides AK1163 were determined by acid production from arabinose and dextran formation from sucrose. Because strain AK1163 produced an acid from arabinose and dextran from sucrose, it was identified as Leu. mesenteriodes ssp. mesenteroides.

Species identification of the 9 strains (Tables 2 and 3) suspected as Achromobacter sp. bacteria was performed by determining oxidation of xylose medium.
None of the strains were able to oxidize xylose and they were consequently identified as $A$. denitrificans.

Pseudomonas fluorescens AK1195 and AK1196 genetically identified were confirmed as $P$. fluorescens by the ability to liquefy gelatin.

Using the culture-dependent analysis, the spoilage bacteria were isolated and the spoilage microbiota in the commercial custard creams was determined (Table 4). This showed that spoilage of custard creams was caused by bacilli, enterococci, staphylococci, lactic acid bacteria, psychrotrophic gram-negative motile rods, or eukaryal cells.

\section{Culture-Independent Analysis}

In addition to the culture-dependent analysis, spoilage bacterial communities in the commercial custard creams were determined with a culture-independent analysis using the PCR-DGGE technique and DNA sequencing. Sample solutions for the PCR-DGGE containing the $16 \mathrm{~S}$ rDNA V6-8 region with a GC clamp were amplified from the total DNA in the putrid custard creams. Representative bands (numbered 1 to 21) from the DGGE profiles are shown in Figure 1. The DNA amplicons extracted from each band were sequenced and their homologies with closest relatives in the GenBank database were determined using BLAST comparisons (Table 5). The microbiota found using the cultureindependent method were the same species (B. amyloliquefaciens, B. cereus, B. subtilis, Staph. warneri, E. faecalis, Lc. lactis, Leu. mesenteroides, and Pseudomonas sp.) as those isolated using the culture-dependent analysis; however, Anoxybacillus sp., Caurobacter sp., 


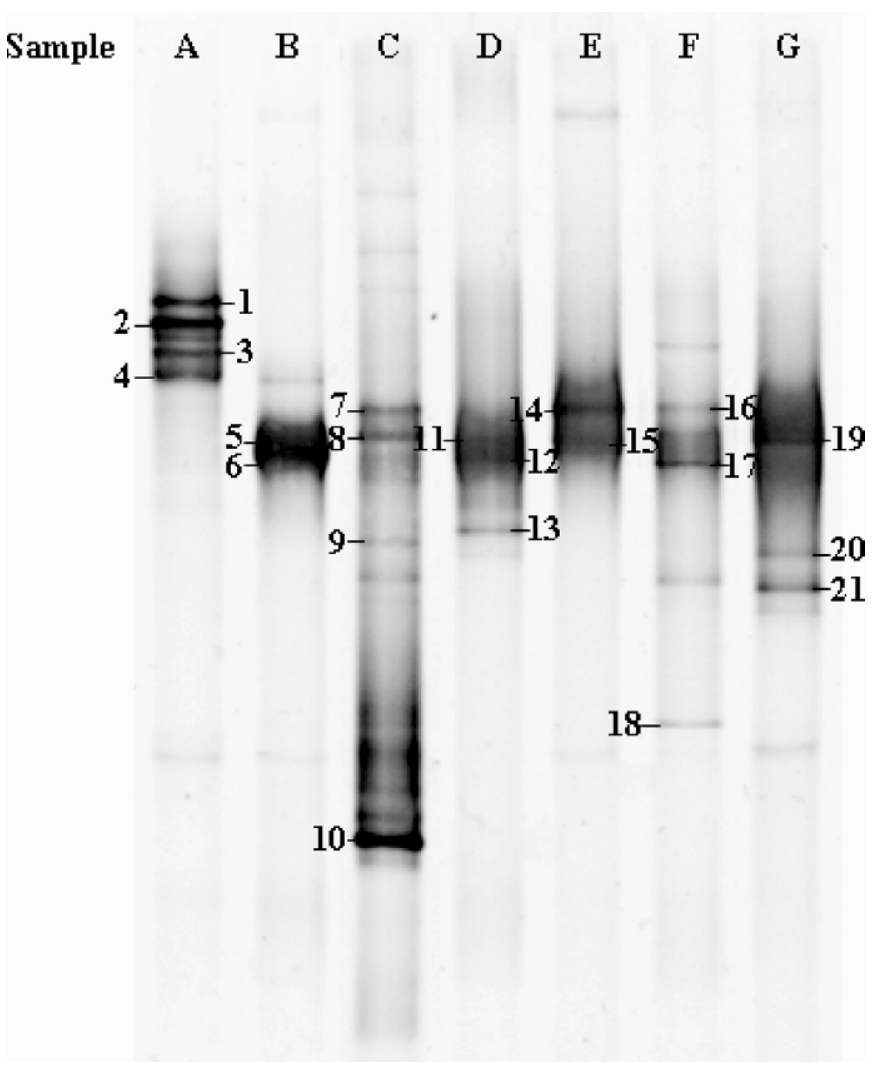

Figure 1. Polymerase chain reaction-denaturing gradient gel electrophoresis profiles of the V6-8 region of 16S rDNA prepared from putrid custard creams. The sequenced bands (1-21) are identified.

and Streptococcus sp. bacteria were not isolated by the culture-dependent method but found using the independent method. Achromobacter denitrificans was detected in the culture-dependent analysis and was not found using the independent method. The spoilage microbiota in the commercial custard creams determined using the culture-independent method was similar to that using the culture-dependent method.

\section{DISCUSSION}

A highly nutritive food such as custard cream is easily spoiled by multiplication of specific microbial contaminants similar to using high-nutrient selective media. To lower the risk of spoilage microbiota in a target food, the identity of the organisms should be known. However, spoilage communities in nonfermented processed products such as custard cream are not understood using molecular biological techniques, whereas the bacterial communities in fermented dairy products such as cheese (Randazzo et al., 2002) and yogurt (Fasoli et al., 2003) have been comprehensively investigated. In this study, the spoilage microbiota in putrid

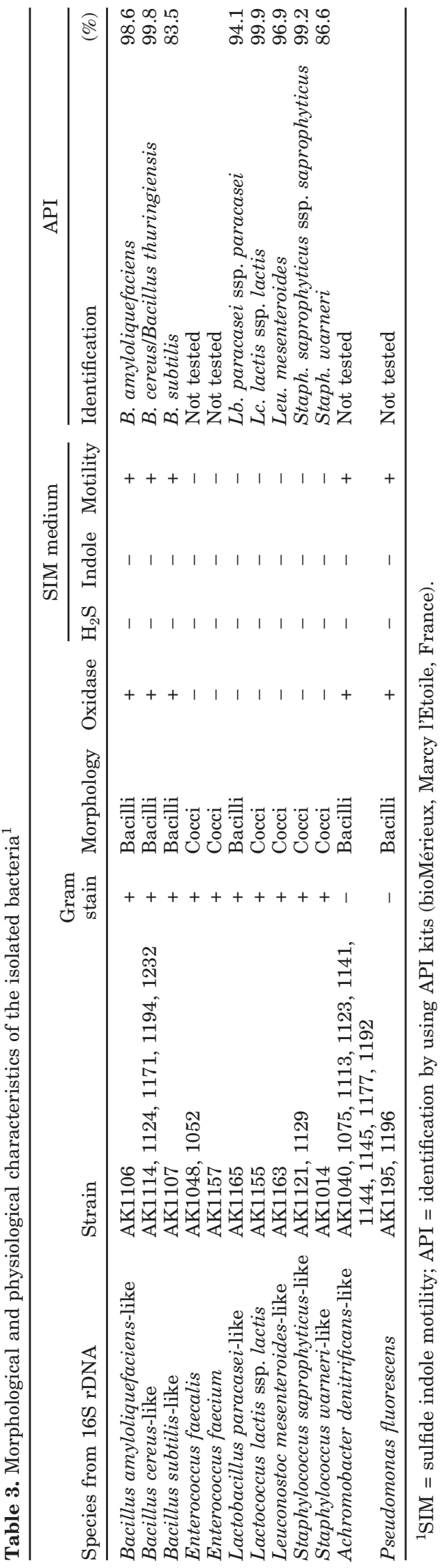

Journal of Dairy Science Vol. 91 No. 8, 2008 
Table 4. The spoilage microbiota in the commercial custard creams using the culture-dependent method

\begin{tabular}{llr}
\hline Sample & Identified species & Ratio (\%) \\
\hline $\mathrm{A}$ & Staphylococcus warneri & $33 / 33(100)$ \\
$\mathrm{B}$ & Enterococcus faecalis & $32 / 33(97.0)$ \\
& Achromobacter denitrificans & $1 / 33(3.0)$ \\
$\mathrm{C}$ & A. denitrificans & $23 / 39(59.0)$ \\
& Eukarya & $16 / 39(41.0)$ \\
$\mathrm{D}$ & Bacillus cereus & $19 / 31(61.3)$ \\
& Staphylococcus saprophyticus ssp. saprophyticus & $7 / 31(22.6)$ \\
& A. denitrificans & $2 / 31(6.5)$ \\
& Bacillus amyloliquefaciens & $2 / 31(6.5)$ \\
& Bacillus subtilis ssp. subtilis & $1 / 31(3.2)$ \\
$\mathrm{E}$ & A. denitrificans & $13 / 32(40.6)$ \\
& Leuconostoc mesenteroides ssp. mesenteroides & $8 / 32(25.0)$ \\
& Lactococcus lactis ssp. lactis & $7 / 32(21.9)$ \\
& Lactobacillus paracasei ssp. paracasei & $2 / 32(6.3)$ \\
& Enterococcus faecium & $1 / 32(3.1)$ \\
& Eukarya & $1 / 32(3.1)$ \\
$\mathrm{F}$ & A. denitrificans & $12 / 23(52.2)$ \\
& Eukarya & $8 / 23(34.8)$ \\
$\mathrm{G}$ & B. cereus & $3 / 23(13.0)$ \\
& Eukarya & $18 / 37(48.6)$ \\
& A. denitrificans & $15 / 37(40.5)$ \\
& B. cereus & $2 / 37(5.4)$ \\
& Pseudomonas fluorescens & $2 / 37(5.4)$ \\
\hline
\end{tabular}

custard creams was determined using culture-dependent and independent methods.

Using the culture-dependent analysis, we isolated and identified bacilli (B. amyloliquefaciens, B. cereus, and B. subtilis ssp. subtilis), staphylococci (Staph. saprophyticus ssp. saprophyticus and Staph. warneri), lactic acid bacteria (E. faecalis, E. faecium, Lb. paracasei ssp. paracasei, Lc. lactis ssp. lactis, and Leu. mesenteroides ssp. mesenteroides), and gram-negative bacteria (A. denitrificans and P. fluorescens) as the principal spoilage bacteria in the custard creams (Table 4). The dominant bacterial species was the psychrotrophic gram-negative $A$. denitrificans detected in 6 samples (66 colonies) of the 7 samples (228 colonies; Table 4). Achromobacter denitrificans and $P$. fluorescens are generally known as heat-sensitive psychrotrophic gramnegative motile rods isolated frequently in rotten milk and eggs (Ray, 2004). It is therefore suspected that they contaminated the custard creams after heat pasteurization and increased under refrigerated storage and during the sales period; these species were barely detected in the shelf-stable samples (A and B) that underwent

Table 5. The spoilage microbiota in the commercial custard creams using the culture-independent method

\begin{tabular}{|c|c|c|c|}
\hline Sample & Band & Closest relative & Identity $(\%)$ \\
\hline \multirow[t]{3}{*}{ A } & 1 & Staphylococcus pasteuri strain LF-2/Staph. warneri ATCC27836 & 99 \\
\hline & 2 & Staph. pasteuri strain LF-2/Staph. warneri ATCC27836 & 99 \\
\hline & 3 & Staph. pasteuri strain LF-2/Staph. warneri ATCC27836 & 99 \\
\hline \multirow[t]{2}{*}{ B } & 5 & Enterococcus faecalis strain GM/Lactobacillus plantarum strain PFK2 & 99 \\
\hline & 6 & E. faecalis strain GM/Lb. plantarum strain PFK2 & 99 \\
\hline $\mathrm{C}$ & 7 & Uncultured bacterium clone Thompsons 87 & 89 \\
\hline \multirow[t]{3}{*}{$\mathrm{D}$} & 11 & Bacillus atrophaeus strain BCRC 17123/Bacillus pumilus strain XJU-4/B. subtilis strain N10 & 97 \\
\hline & 12 & B. subtilis strain N10 & 97 \\
\hline & 13 & B. subtilis strain h-g/Bacillus amyloliquefaciens strain BCRC14193 & 99 \\
\hline \multirow[t]{2}{*}{$\mathrm{E}$} & 14 & Lactococcus lactis strain P2 & 100 \\
\hline & 15 & Leuconostoc mesenteroides isolate F170 & 85 \\
\hline $\mathrm{F}$ & 16 & Streptococcus sp. 2061A & 95 \\
\hline
\end{tabular}


severe heat treatment during food reprocessing. Further, because heat-sensitive eukaryal fungi were also not detected in samples A and B, it is suggested that shelf-stable custard cream may be spoiled only by the heat-resistant gram-positive bacteria. The predominant spoilage bacterial species of the gram-positive species was $B$. cereus isolated in 3 samples ( 24 colonies) of 7 samples (228 colonies; Table 4). Bacillus cereus is well known as a major food spoilage and poisoning organism forming heat-resistant spores and producing toxins that cause emetic and diarrheal syndromes (Schoeni and Wong, 2005). Some strains of B. cereus isolated in this study survived heat pasteurization, presumably using spore forms. This suggests that measures such as food preservatives and refrigeration should be considered during custard cream formulation and preservation, so that heat-resistant spores do not propagate.

In culture-independent analysis, PCR-DGGE for the V6-8 region on 16S rDNA was performed (Figure 1); PCR-DGGE for the V3 region was rejected because there were fewer bands for the V3 region (data not shown) than for the V6-8 region (Figure 1). A sequence and homology search of the DGGE banding amplicons in the V6-8 region determined that the spoilage microbiota in the commercial custard creams consisted of bacilli, staphylococci, lactic acid bacteria, Pseudomonas sp., Anoxybacillus sp., Caulobacter sp., and Streptococcus sp. bacteria (Table 5). The plural bands in the V68 region were identified as the same species, possibly indicating that single-base-change mutants were caused by heteroduplex formation (Jensen and Straus, 1993). The spoilage microbiota detected using the culture-independent method was similar to that in the culture-dependent analysis. However, the dominant species in the culture-dependent analysis (A. denitrificans) was not detected using the culture-independent analysis. The reason may be insufficient DNA extraction from the small-sized $A$. denitrificans using the bead extraction method or PCR bias using unsuitable universal primers (Kanagawa, 2003). Anoxybacillus sp., Caulobacter sp., and Streptococcus sp. bacteria were genetically detected only by the culture-independent analysis, in which it is difficult to determine whether they had existed before or were viable after heat pasteurization, because viable and dead cells in the putrid custard creams were detected using this $16 \mathrm{~S}$ rDNA detection method.

Most of the detected spoilage bacteria in this study were the same as those detected previously in rotten milk (Boor and Murphy, 2002). This result suggests that spoilage bacteria growing in a raw material are easy to grow in a processed food made from the same raw material. As the first step for safe food preservation, food manufacturers should understand the spoil- age microbiota in a target food to select optimal preservatives and thus reduce the need for food additives. However, in the real-world situation, indistinct and inappropriate preservatives are qualitatively and quantitatively added to processed foods and this is not preferable for manufacturers and consumers. If the spoilage microbiota is known as reported here, antimicrobial measures suitable for each food can be adopted.

The 2 experimental techniques used herein differ in important ways. Using the culture-dependent method, viable cells were isolated and only cultivable cells could be detected, whereas using the culture-independent method, both cultivable and uncultivable species are detected rapidly and easily. However, viable cells cannot be isolated using the culture-independent method and bacterial species cannot be completely identified because the method relies on extracted DNA or RNA sequences as templates for PCR. A more accurate microbiota analysis is possible by combining both methods and compensating for their strengths and weaknesses. Previously, combined analyses have been performed on soil (Ellis et al., 2003) and fermented food microbiota (Rantsiou et al., 2005). However, few studies concerning spoiled foods using the culture-independent method have been performed. Our data suggest that more spoilage microbiota in various food products need to be examined using both the culture-dependent and independent methods to develop future food preservation methods.

\section{REFERENCES}

Amann, R. I., W. Ludwig, and K. H. Schleifer. 1995. Phylogenetic identification and in situ detection of individual microbial cells without cultivation. Microbiol. Rev. 59:143-169.

Ampe, F., N. ben Omar, C. Moizan, C. Wacher, and J. P. Guyot. 1999. Polyphasic study of the spatial distribution of microorganisms in Mexican pozol, a fermented maize dough, demonstrates the need for cultivation-independent methods to investigate traditional fermentations. Appl. Environ. Microbiol. 65:5464-5473.

Ampe, F., A. Sirvent, and N. Zakhia. 2001. Dynamics of the microbial community responsible for traditional sour cassava starch fermentation studied by denaturing gradient gel electrophoresis and quantitative rRNA hybridization. Int. J. Food Microbiol. 65:4554 .

ben Omar, N., and F. Ampe. 2000. Microbial community dynamics during production of the Mexican fermented maize dough pozol. Appl. Environ. Microbiol. 66:3664-3673.

Beukes, E. M., B. H. Bester, and J. F. Mostert. 2001. The microbiology of South African traditional fermented milks. Int. J. Food Microbiol. 63:189-197.

Blazevic, D. J., M. H. Koepche, and J. M. Matsen. 1973. Incidence and identification of Pseudomonas fluorescens and Pseudomonas putida in the clinical laboratory. Appl. Microbiol. 25:107-110.

Boor, K. J., and S. C. Murphy. 2002. Microbiology of market milks. Pages 91-122 in Dairy Microbiology Handbook. 3rd edition. R. K. Robinson, ed. John Wiley and Sons Inc., New York, NY.

Bravo, A., S. Sarabia, L. Lopez, H. Ontiveros, C. Abarca, A. Ortiz, M. Ortiz, L. Lina, F. J. Villalobos, G. Pena, M. E. Nunez Valdez, M. Soberon, and R. Quintero. 1998. Characterization of cry genes in a Mexican Bacillus thuringiensis strain collection. Appl. Environ. Microbiol. 64:4965-4972. 
Cenci-Goga, B. T., S. Crotti, S. Costarelli, C. Rondini, M. Karama, and P. Bennett. 2004. Detection of tet $(\mathrm{M})$ gene from raw milk by rapid DNA extraction followed by a two-step PCR with nested primers. J. Food Prot. 67:2833-2838.

Ceron, J., A. Ortiz, R. Quintero, L. Guereca, and A. Bravo. 1995. Specific PCR primers directed to identify cryI and cryIII genes within a Bacillus thuringiensis strain collection. Appl. Environ. Microbiol. 61:3826-3831.

Chun, J., and K. S. Bae. 2000. Phylogenetic analysis of Bacillus subtilis and related taxa based on partial gyrA gene sequences. Antonie Van Leeuwenhoek 78:123-127.

Cocolin, L., L. Bisson, and D. A. Mills. 2000. Direct profiling of the yeast dynamics in wine fermentations. FEMS Microbiol. Lett. 189:81-87.

Cocolin, L., M. Manzano, C. Cantoni, and G. Comi. 2001. Denaturing gradient gel electrophoresis analysis of the $16 \mathrm{~S}$ rRNA gene V1 region to monitor dynamic changes in the bacterial population during fermentation of Italian sausages. Appl. Environ. Microbiol. 67:5113-5121.

Cotter, P. D., C. Hill, and R. P. Ross. 2005. Bacteriocins: Developing innate immunity for food. Nat. Rev. Microbiol. 3:777-788.

Ellis, R. J., P. Morgan, A. J. Weightman, and J. C. Fry. 2003. Cultivation-dependent and -independent approaches for determining bacterial diversity in heavy-metal-contaminated soil. Appl. Environ. Microbiol. 69:3223-3230.

Ercolini, D. 2004. PCR-DGGE fingerprinting: Novel strategies for detection of microbes in food. J. Microbiol. Methods 56:297-314.

Fasoli, S., M. Marzotto, L. Rizzotti, F. Rossi, F. Dellaglio, and S. Torriani. 2003. Bacterial composition of commercial probiotic products as evaluated by PCR-DGGE analysis. Int. J. Food Microbiol. 82:59-70.

Fontana, C., P. S. Cocconcelli, and G. Vignolo. 2005a. Monitoring the bacterial population dynamics during fermentation of artisanal Argentinean sausages. Int. J. Food Microbiol. 103:131-142.

Fontana, C., G. Vignolo, and P. S. Cocconcelli. 2005b. PCR-DGGE analysis for the identification of microbial populations from Argentinean dry fermented sausages. J. Microbiol. Methods 63:254-263.

Harmon, S. M. 1982. New method for differentiating members of the Bacillus cereus group: Collaborative study. J. Assoc. Off. Anal. Chem. 65:1134-1139.

Iwamoto, T., K. Tani, K. Nakamura, Y. suzuki, M. Kitagawa, M. Eguchi, and M. Nasu. 2000. Monitoring impact of in situ biostimulation treatment on groundwater bacterial community by DGGE. FEMS Microbiol. Ecol. 32:129-141.

Jensen, M. A., and N. Straus. 1993. Effect of PCR conditions on the formation of heteroduplex and single-stranded DNA products in the amplification of bacterial ribosomal DNA spacer regions. PCR Methods Appl. 3:186-194.
Kanagawa, T. 2003. Bias and artifacts in multitemplate polymerase chain reaction (PCR). J. Biosci. Bioeng. 96:317-323.

Kawai, Y., and T. Saito. 2002. Bacteriocins of lactic acid bacteria. Pages 99-112 in The Biol.-defensive Function of Dairy Foods. K. Shimazaki and H. Otani, ed. Research Signpost, Trivandrum, India.

Kroes, I., P. W. Lepp, and D. A. Relman. 1999. Bacterial diversity within the human subgingival crevice. Proc. Natl. Acad. Sci. USA 96:14547-14552.

Lane, D. J. 1991. 16S/23S rRNA sequencing. Pages 115-175 in Nucleic Acid Techniques in Bacterial Systematics. E. R. Stackebrandt and M. Goodfellow, ed. John Wiley and Sons Inc., New York, NY.

Lee, J. S., G. Y. Heo, J. W. Lee, Y. J. Oh, J. A. Park, Y. H. Park, Y. R. Pyun, and J. S. Ahn. 2005. Analysis of kimchi microflora using denaturing gradient gel electrophoresis. Int. J. Food Microbiol. 102:143-150.

Miambi, E., J. P. Guyot, and F. Ampe. 2003. Identification, isolation and quantification of representative bacteria from fermented cassava dough using an integrated approach of culture-dependent and culture-independent methods. Int. J. Food Microbiol. 82:111-120.

Muyzer, G., E. C. de Waal, and A. G. Uitterlinden. 1993. Profiling of complex microbial populations by denaturing gradient gel electrophoresis analysis of polymerase chain reaction-amplified genes coding for 16S rRNA. Appl. Environ. Microbiol. 59:695-700.

Obodai, M., and C. E. Dodd. 2006. Characterization of dominant microbiota of a Ghanaian fermented milk product, nyarmie, by culture- and nonculture-based methods. J. Appl. Microbiol. 100:1355-1363.

Randazzo, C. L., S. Torriani, A. D. Akkermans, W. M. de Vos, and E. E. Vaughan. 2002. Diversity, dynamics, and activity of bacterial communities during production of an artisanal Sicilian cheese as evaluated by $16 \mathrm{~S}$ rRNA analysis. Appl. Environ. Microbiol. 68:1882-1892.

Rantsiou, K., R. Urso, L. Iacumin, C. Cantoni, P. Cattaneo, G. Comi, and L. Cocolin. 2005. Culture-dependent and -independent methods to investigate the microbial ecology of Italian fermented sausages. Appl. Environ. Microbiol. 71:1977-1986.

Ray, B. 2004. Spoilage of specific food groups. Pages 269-288 in Fundamental Food Microbiology. 3rd edition. B. Ray, ed. CRC Press, Boca Raton, FL.

Rosenquist, H., L. Smidt, S. R. Andersen, G. B. Jensen, and A. Wilcks. 2005. Occurrence and significance of Bacillus cereus and Bacillus thuringiensis in ready-to-eat food. FEMS Microbiol. Lett. 250:129-136.

Schoeni, J. L., and A. C. Wong. 2005. Bacillus cereus food poisoning and its toxins. J. Food Prot. 68:636-648.

Torsvik, V., F. L. Daae, R. A. Sandaa, and L. Ovreas. 1998. Novel techniques for analyzing microbial diversity in natural and perturbed environments. J. Biotechnol. 17:53-62. 